\title{
$-462 \operatorname{sen}^{2}+6$ (CLASSIFICATION) DTh \\ GENERAL ELECTRIC
}

hANFORD ATOMIC PRODUCTS OPERATION - RICHLAND, WASHINGTON

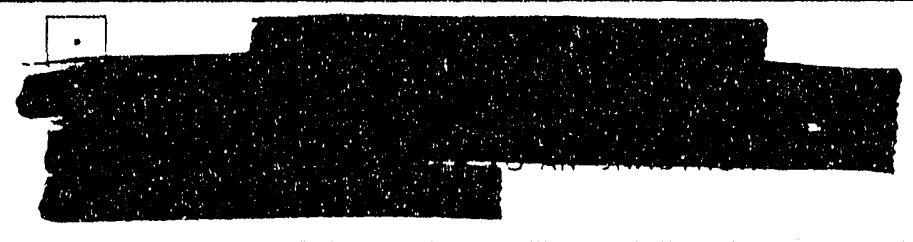

OTHER OFFICIAL CLASSIFIED INFORMATION

THIS MATERIAL CONTAINS INFORMATION AFFECTING THE NATIONAL DEFENSE OF THE UNITED STATES WITHIN THE MEANING OF THE ESPIONAGE LAWS, TITLE 18, U.S.C., SECS. 793 AND 794, THE TRANSMISSION OR REVELATION OF WHICH IN ANY MANNER TO AN UNAUTHORIZED PERSON IS PROHIBITED BY LAW.

XCs.

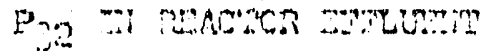

AUTHOR

‥ 7. 3olinas

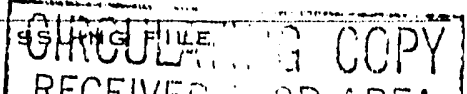
RECEIVED OD AREA

\section{MAY i 1051}

REIUKIS 10

TECHNICAL IAFORAATON-FH

THIS DOCUMENT MUST NOT BE LEFT UNATTENDED OR WHERE AN UNAUTHORIZED PERSON MAY HAVE ACCESS TO IT. WHEN NOT IN USE, IT MUST BE STORED IN AN APPROVED LOCKED REPOSITORY WITHIN AN APPROVED GUARDED AREA. WHILE. IT IS IN YOUR POSSESSION AND UNTIL. YOU HAVE OBTAINED A SIGNED RECEIPT FROM CLASSIFIED FILES, IT IS YOUR RESPONSIBILITY TO KEEP IT AND ITS CONTENTS WITHIN THE LIMITS OF THIS PROJECT AND FROM ANY UNAUTHORIZED PERSON. ITS TRANSMITTAL TO, AND STORAGE AT YOUR PLACE OF RESIDENCE IS PROHIBITED. IT IS NOT TO BE DUPLICATED. IF ADDITIONAL COPIES ARE REQUIRED, OBTAIN THEM FROM THE RELATED ISSUING FILE. ALL PERSONS READING THIS DOCUMENT ARE REQUESTED TO SIGN IN THE SPAEE FROVIDED BELOW.

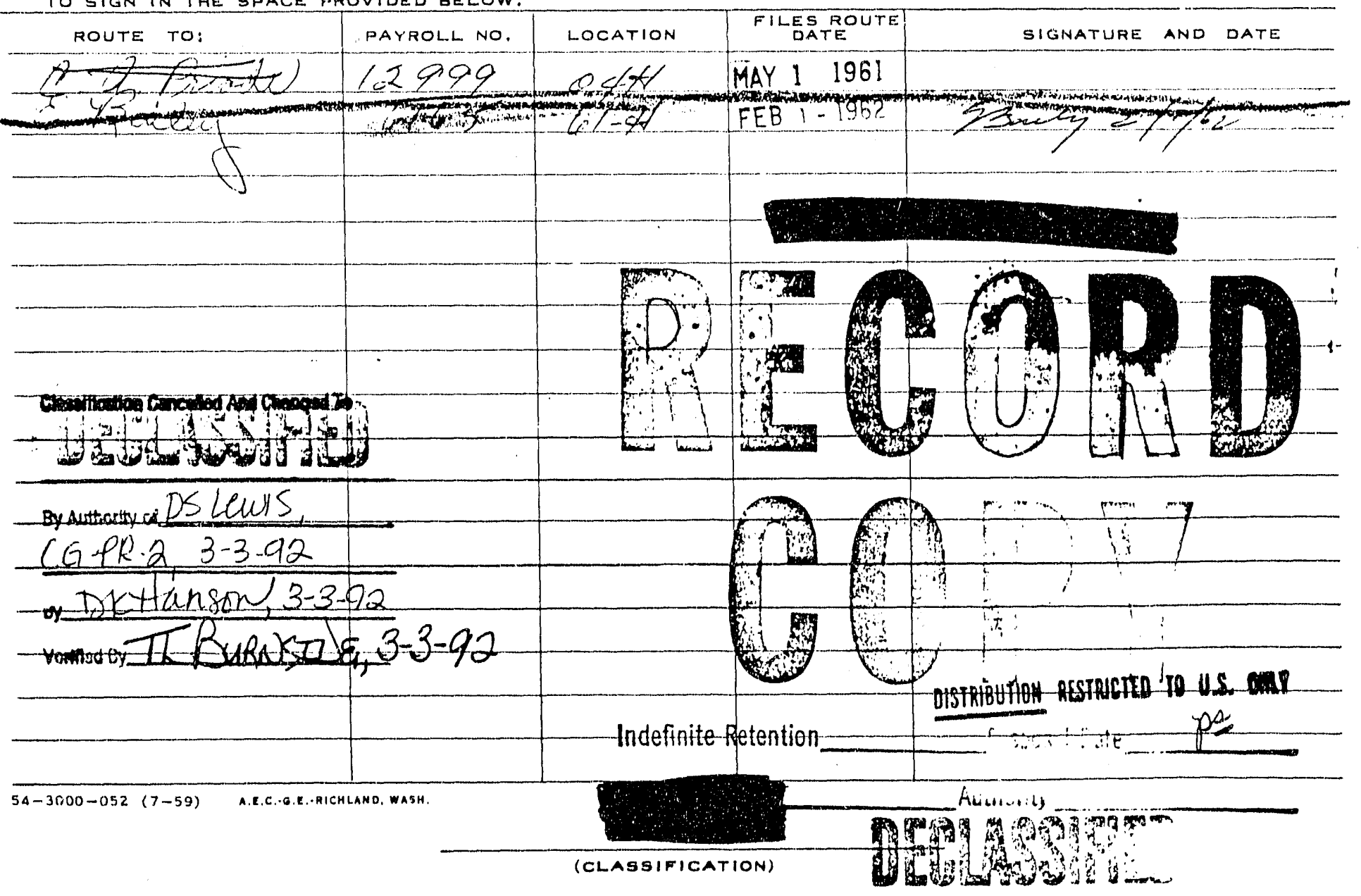




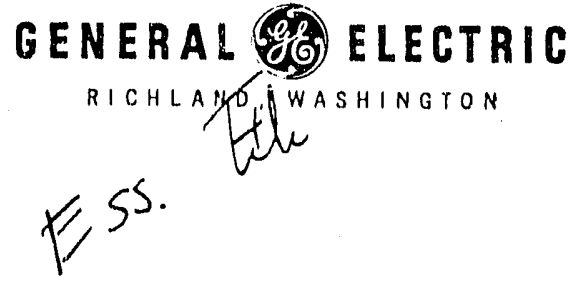

C. E. Reed, Manager Product Cost and Budgets

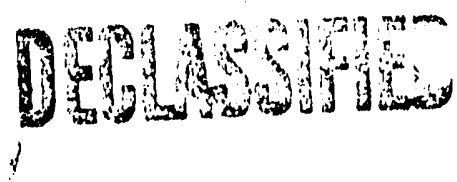

$$
\begin{aligned}
& \text { คニこミルレั } \\
& \therefore 1961
\end{aligned}
$$

C. A. PRIODE
$2 \pi 760436$

Page 1

April 28, 1961

\section{COST ESTIMALT FOR REDUCTION OF P32 IN REACTOR EFFLUENT}

The proposal to reduce $P_{32}$ in reactor effluent by Increasing aluminum sulphate and bauxite feed to $18 \mathrm{ppm}$ while maintaining $7.0 \mathrm{pH}$ water is estimated to cost $\$ 1368000$. This represents an increase of $\$ 507000$ over FY 1962 budgeted cost for aluminum sulphate, bauxite and sulphuric acid.

The cost estimate was based on the following assumptions. Detail calculations are shown on Schedule I, attached.

\section{Assumptions}

1. Average TOE for six old areas 82.0 percent.

2. Average TOE for $K$ Areas 85.0 percent.

3. Gallons treated based on six-month average flow to 183 head house adjusted for TOE.

4. Iiquid aluminum sulphate used in $D, D R, F, H$ and $K$ areas using current contract average price of $\$ 43.25$ per ton.

5. Bauxite used in $B$ and. $C$ areas at $\$ 34.45$ per ton.

6. Sulphuric acid priced at $\$ 25.00$ per ton.

Instajlation of kauxite feed facilities in all areas, currently a project proposal, would reduce the estimated FY 1962 cost $\$ 559000 /$ year or $\$ 46500 /$ month when completed.

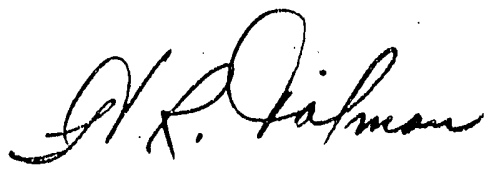

\section{R. Tolman}

Product Cost and Budgets

Attachment

HRT : Jd

ce:I.RT Jessen

2.CA Prlode/E. Bailey

3.JH Roberts/V Schwtnberg

4.OC Schroeder

5.SH Small

6.Essential Mat. File/HR Tolman

7.CE Reed - 300 Fillo

ron

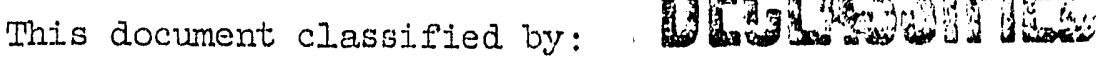
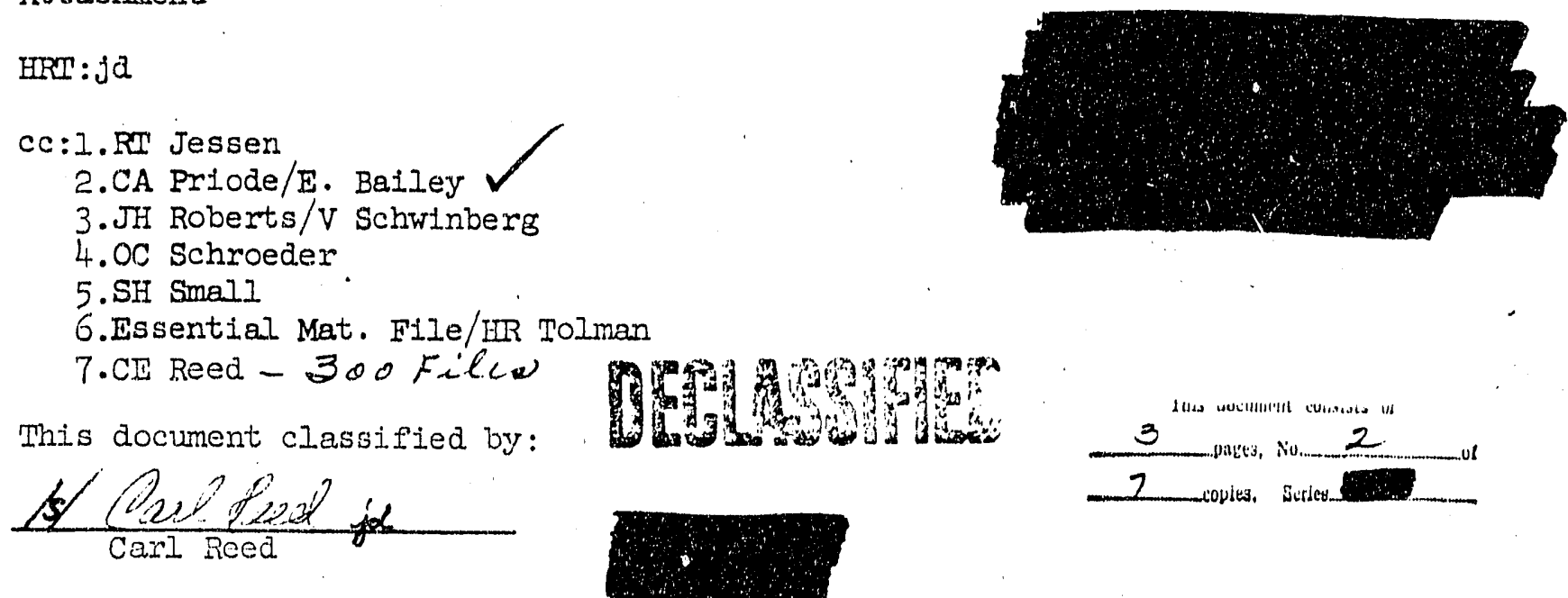
Schedule I

\section{DETAIL CALCULATIONS}

A. $24 \mathrm{ppm}$ of aluminum sulphate requires no acid to maintain $7.0 \mathrm{pH}$.

B. $12 \mathrm{ppm}$ of acid requires no aluminum sulphate to maintain $7.0 \mathrm{pH}$.

C. 1 ppm of bauxite and $2 \mathrm{ppm}$ of acid is equivalent to $4 \mathrm{ppm}$ of aluminum

D. $18 \mathrm{ppm}$ of al um represents $150.3 \mathrm{H} / \mathrm{milli}$ on gallons and requires $3 \mathrm{ppm}$ of acid (25.1\#/million gallons) to maintain $7.0 \mathrm{pH}$.

E. 525600 minutes per year.

F. Average flows to 183 head house based on past six months adjusted for ToE.
B $68100 \mathrm{cpm}$
C $\quad 102600 \mathrm{gpm}$
D $\quad 87200 \mathrm{gpm}$
DR $61400 \mathrm{gpm}$
F $\quad 80000 \mathrm{gpm}$
$\mathrm{H} \quad 79600 \mathrm{gpm}$
KE $165400 \mathrm{gpm}$
KW $165400 \mathrm{gpm}$
82.0 TOE
82.0 T'OE
82.0 TOE
82.0 TOE
82.0 TOE
82.0 TNE
85.0 TOF
85.0 TUE

G. Average flow of $\mathrm{D}, \mathrm{DR}, \mathrm{F}, \mathrm{H}, \mathrm{KE}$ and $\mathrm{KWW}=639000$ gpm $\times 525600$ minutes per year $=335858$ milition gallons.

$335858 \mathrm{MM} \mathrm{gals} / \mathrm{yr} \times 1.50 .3 \#$ of alum/MM $=25240 \mathrm{Tons}$

$335858 \mathrm{MM}$ gals/yr $\mathrm{x}$ 25. I\# of acid/MM $=4215$ Tons

H. Average fllow of $B$ and $C=170700 \mathrm{gpm} \times 525600$ minutes per year $=$

89720 million gallons.

$89720 \mathrm{MM}$ gals/yr $\times 150.3 \#$ of alum/MM $=6742$ Tons of alum

Equivalent to 1686 Tons bauxite

3372 Tons ucid

I. $\mathrm{D}, \mathrm{DR}, \mathrm{F}, \mathrm{H}, \mathrm{KE}$ and $\mathrm{KW}$

25240 Tons alum @ $\$ 43.25 /$ Ton =

4215 Tons acid@ @ $\$ 25.00 /$ Ton $=$

$\$ 1091630$

105375

$\$ 1197005$

J. $B$ and $C$

1686 Tons bauxite @ $\$ 34.45 /$ Ton $=$

3372 Tons acid for $\$ 58083$

1376 Tons actd 84300

1126 Tons actd for pH @ \$25.00/Ton =

$28 \quad 150$

170533

Total cost @ 18 ppm FY 1962 under present feed system

$\$ 1367 \quad 538$

K. $D, D R, F, H, K E$ and $K W$

Converted to bauxite feed

25240 Tons alum $\div 4=6310$ Tons bauxite@ $\$ 34.45=\$ 217380$

6310 Tons bauxite $x_{2}=12620$ Tons acid @ $\$ 25.00=315500$

4215 Tons acid for pH control @ \$25.00

Using bauxite a.11 areas

$=\frac{105375}{\$ 638255}$

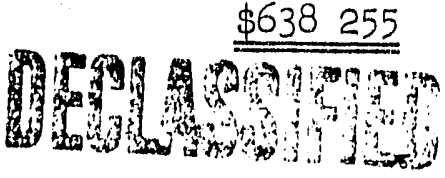




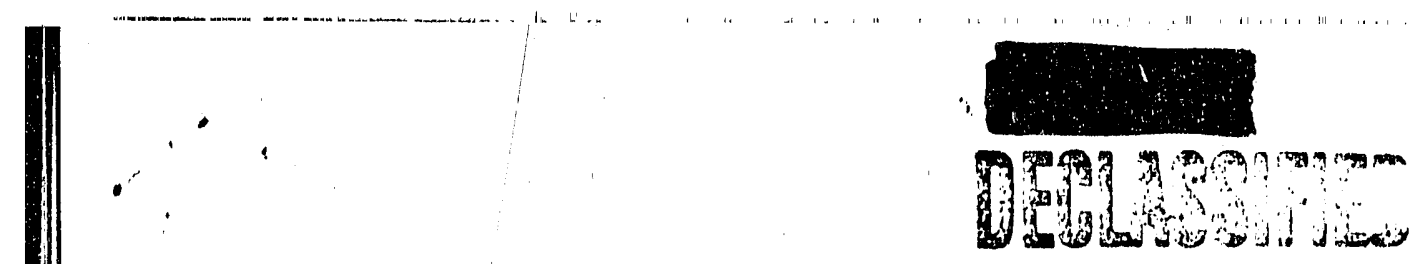

Schedule I (Continued)

I. Reduction due to bauxite conversion in D, DR, F, H, KE and KW

I.

K.

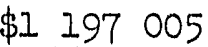

$(638255)$

$\$ 558750$ Annual savings for full conversion

Equivalent to $\$ 46500$ per month.

M. FY-1962 Chemical Budget

Aluminum sulphate
Sulphuric acid
Bauxite

$$
\begin{array}{r}
\$ 525855 \\
308627 \\
26010 \\
\hline \$ 860492 \\
\hline
\end{array}
$$

\title{
DISCLAIMER
}

\begin{abstract}
This report was prepared as an account of work sponscred by an agency of the United States Government. Neither the United States Government nor any agency thereof, nor any of their employees, makes any warranty, express or implied, or assumes any legal liability or responsibility for the accuracy, completeness, or usefulness of any information, apparatus, product, or process disclosed, or represents that its use would not infringe privately owned rights. Reference herein to any specific commercial product, process, or service by trade name, trademark, manufacturer, or otherwise does not necessarily constitute or imply its endorsement, recommendation, or favoring by the United States Government or any agency thereof. The views and opinions of authors expressed herein do not necessarily state or reflect those of the United States Government or any agency thereof.
\end{abstract}

H. R. To'Lman: ja

Product Jost and Budgets April 28, 1961
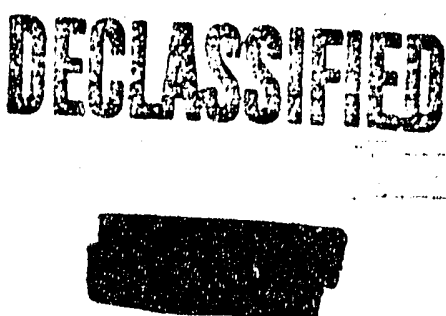

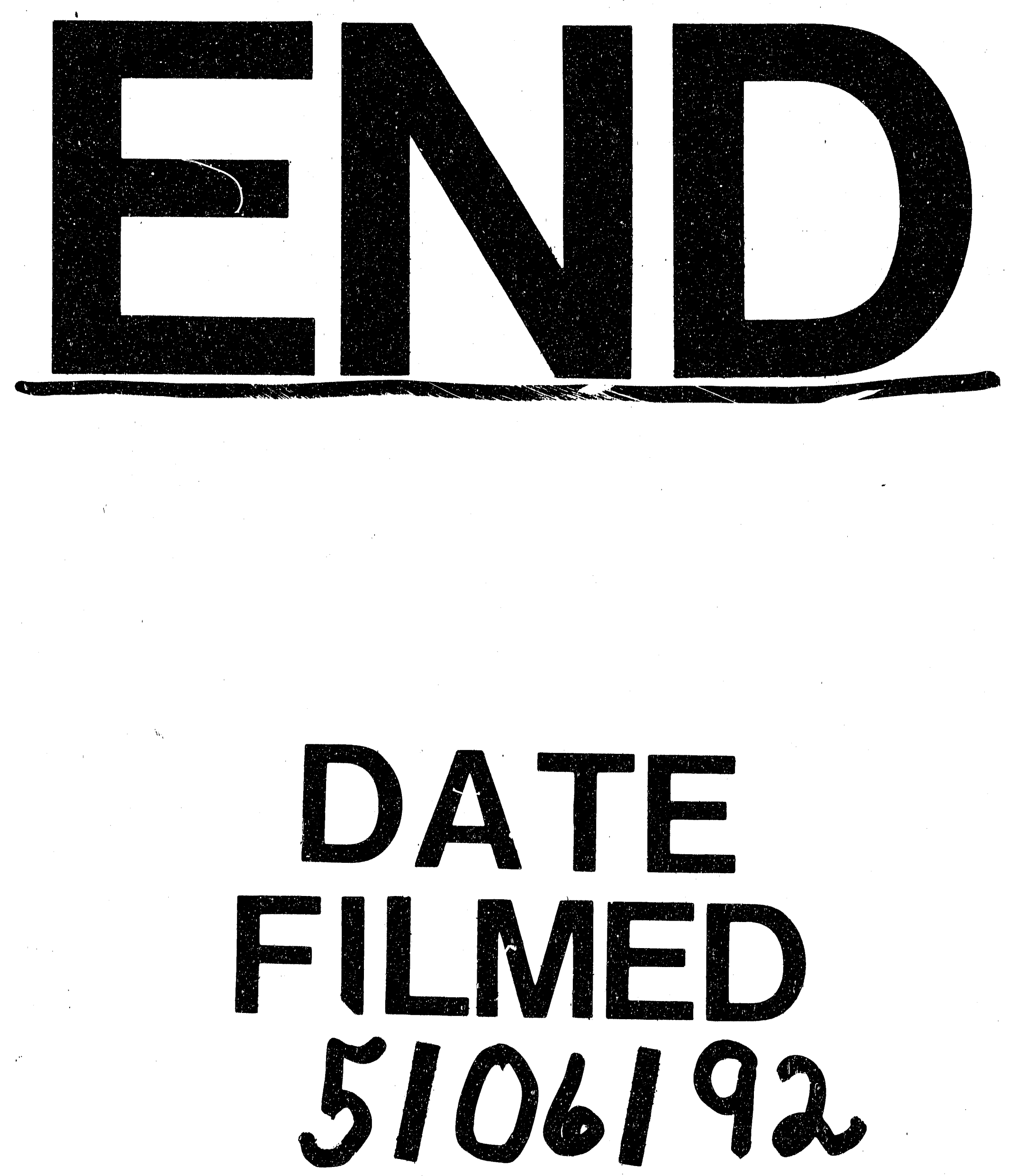


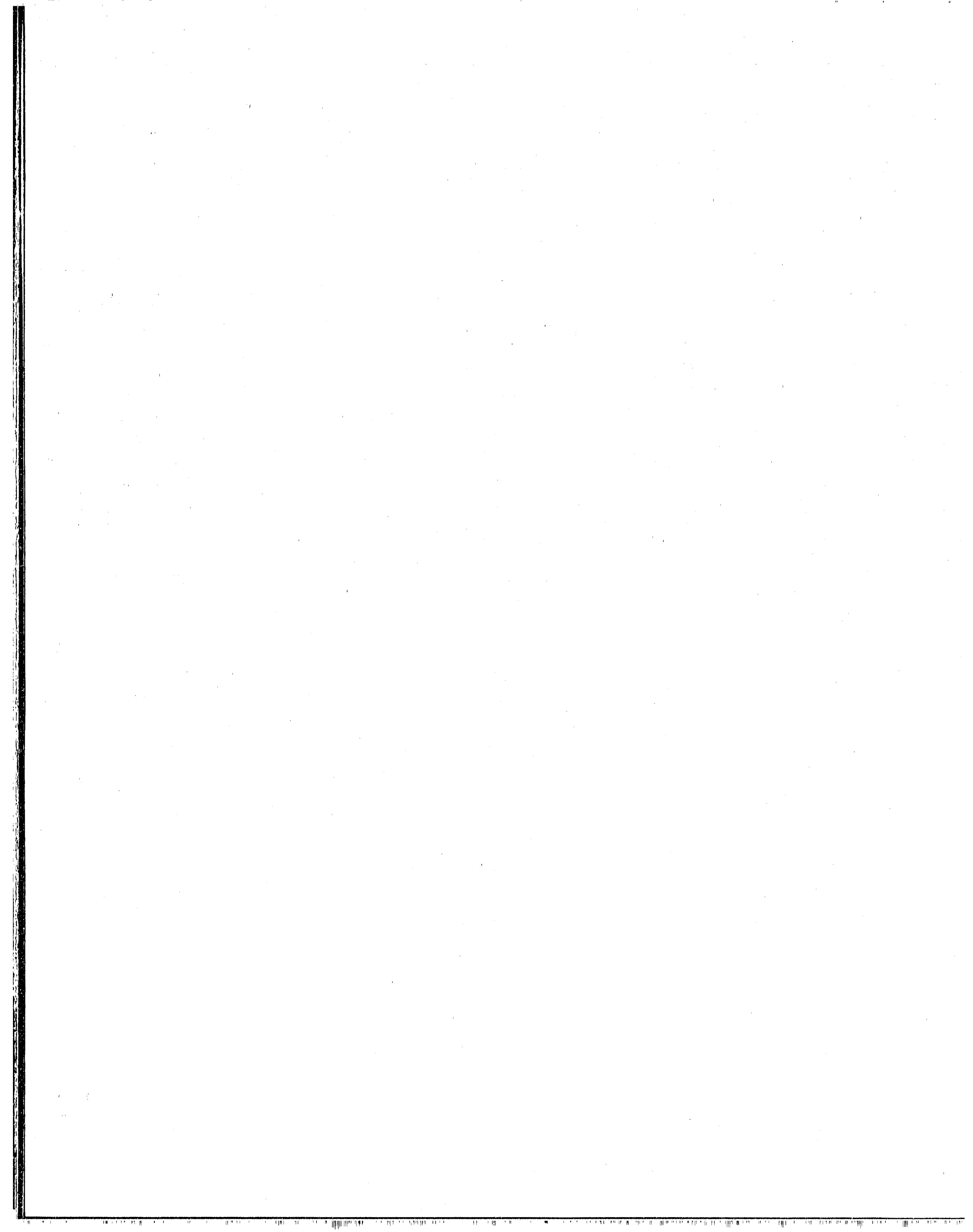

